Pesq. Vet. Bras. 36(7):665-670, julho 2016 DOI: $10.1590 / \mathrm{S} 0100-736 \mathrm{X} 2016000700018$

\title{
Histological features of the placenta and their relation to the gross and data from Thoroughbred mares ${ }^{1}$
}

\author{
Fernanda M. Pazinato ${ }^{2 *}$, Bruna R. Curcio ${ }^{2}$, Cristina G. Fernandes ${ }^{3}$, Lorena S. Feijó ${ }^{4}$, \\ Rubia A. Schmith ${ }^{5}$ and Carlos E.W. Nogueira ${ }^{2}$
}

\begin{abstract}
Pazinato F.M., Curcio B.R., Fernandes C.G., Feijó L.S., Schmith R.A. \& Nogueira C.E.W. 2016. Histological features of the placenta and their relation to the gross and data from Thoroughbred mares. Pesquisa Veterinária Brasileira 36(7):665-670. Departamento de Clínicas Veterinária, Universidade Federal de Pelotas, Campus Universitário s/n, Capão do Leão, RS 96160-000, Brazil. E-mail: fernandampazinato@yahoo.com.br

The placenta is a transitory organ that originates from maternal and fetal tissues, the function of which is transporting nutrients from the mother to the fetus. The aim of this study was describe the histological features of placentas in healthy Thoroughbred mares at foaling and evaluate their relation with the gross placental and data of these mares. For this study 188 Thoroughbred mares were used. It was performed clinical observation for signs of placentitis during daily health checks and ultrasonic examination monthly to assess the fetus and placenta. All of the mares that exhibited clinical signs of placentitis were treated during gestation. The parturition was assisted, the placentas were grossly evaluated and samples were collected immediately after expulsion. The following data were considered for each mare: age, gestational age, number of parturition, time for placental expulsion, umbilical-cord length, placental weight and clinical signs of placentitis. Histological evaluation of the placentas revealed extensive cytoplasmic vacuolization of the epithelial areolar cells, presence of inflammatory infiltrates and hypoplasia-atrophy of the microcotyledons. Most of the gross placental findings were consistent with the histological results. In conclusion the mares with a vacuolated placental chorionic epithelium were older and had experienced a larger number of births. Great part of the mares with inflammatory infiltrates did not showed any clinical signs of placentitis during gestation.
\end{abstract}

INDEX TERMS: Histology, placenta, Thoroughbred mares, vacuolization, infiltrates.

RESUMO.- [Achados histológicos da placenta e sua relação com seus aspectos macroscópicas e dados de éguas Puro Sangue Inglês.] A placenta é um órgão transitório originado do tecido fetal e materno, com função de transportar nutrientes da mãe para o feto. 0 objetivo deste estudo foi descrever os achados histológicos das placentas

\footnotetext{
${ }^{1}$ Received on February 5, 2016.

Accepted for publication on April 28, 2016.

${ }^{2}$ Departamento de Clínicas Veterinária, Universidade Federal de Pelotas (UFPel), Campus Universitário s/n, Capão do Leão, RS 96160-000, Brazil. *Corresponding author: fernandampazinato@yahoo.com.br

${ }^{3}$ Departamento de Patologia Animal, UFPel, Campus Universitário s/n, Capão do Leão, RS 96160-000, Brazil.

${ }^{4}$ Research Scholar, University of Illinois, Urbana-Champaign, 507 E. Green Street, IL 61820, USA.

${ }^{5}$ Departamento de Reprodução Animal e Radiologia, Universidade Estadual Paulista "Júlio de Mesquita Filho" (Unesp), Av. Prof. Montenegro, Distrito de Rubião Junior s/n, Botucatu, SP 18618970, Brazil.
}

de éguas Puro Sangue Inglês (PSI) a termo e avaliar sua relação com a macroscopia da placenta e dados dessas éguas. 0 estudo utilizou 188 éguas PSI. Foram realizadas observações clinicas diárias para presença de sinais clínicos de placentite e ultrassonografia mensal para avaliar saúde do feto e placenta. As éguas que apresentaram sinais clínicos de placentite durante a gestação foram tratadas. Os partos foram assistidos, as placentas avaliadas macroscopicamente e coletadas imediatamente após sua expulsão. Como dados das éguas foram considerados: idade, tempo de gestação, número de partos, tempo de eliminação da placenta, comprimento de cordão umbilical, peso da placenta e sinais clínicos de placentite. A avaliação histológica das placentas demonstrou extensiva vacuolização citoplasmática das células do epitélio coriônico das regiões areolares, presença de infiltrados inflamatórios e hipoplasia-atrofia de microcotilédones. A maior parte dos achados macroscópicos da placenta foram condizentes com os resultados de histolo- 
gia. Como conclusão, a vacuolização do epitélio coriônico foi característica de éguas mais velhas e com maior número de partos. Grande parte das éguas com infiltrados inflamatórios não demonstraram sinais clínicos de placentite.

TERMOS DE INDEXAÇÃO: Histologia, placenta, éguas Puro Sangue Inglês, vacuolização, infiltrados.

\section{INTRODUCTION}

The placenta is a transitory organ that originates from maternal and fetal tissues, the function of which is transporting nutrients from the mother to the fetus, as well as promoting metabolic changes and maintaining the pregnancy by performing endocrine functions for the production of hormones (Leiser \& Kaufmann 1994). The equine placenta is a microcotyledonary diffuse epitheliochorial organ that is attached to the entire endometrium. The microcotyledons that cover almost the entire surface of the diffuse allantochorion allow gaseous and hemotrophic maternofetal exchange (Abd-Elnaeim et al. 2006, Wilsher \& Allen 2012).

The development and function of the placenta directly affect the growth and well-being of the fetus in utero. Then, deficits in either the structure or the function of the placenta will be reflected in fetal development (Wilsher et al. 2005). Deviations in the appearance of the placenta from that considered normal provide information of importance to both the mare and the foal (Morresey 2005). Neonatal risk identification should include a systematic evaluation of the placenta, using histopathology to recognize placental impairments that were not obvious during gestation, besides many mares did not show clinical signs of gestational compromise (Le Blanc et al. 2004, Schlafer 2004). By this way, some features in the histophatological evaluation of placenta it's useful to identify problems could have had during pregnancy. In the other hand, some gross features can be questionable lesions.

We hypothesized that: (i) histologic findings are relation with gross evaluation of placenta and clinical characteristics of the mares. (ii) Older mares show particularities in histopathological features. (iii) Degrees of placental inflammation are associated with different grossly and clinical outcomes of the mares.

The aim of this study was describe the histological features of placentas in healthy Thoroughbred mares at foaling and evaluate their relation with the gross placental and clinical characteristics of these mares.

\section{MATERIALS AND METHODS}

It was performed a prospective observational study of a population of Thoroughbred mares $(\mathrm{n}=188)$ from a farm in Aceguá, Rio Grande do Sul, Brazil (3151'55"S; 54²102"0), from 2009 to 2013. These mares were maintained in a semi-extensive system, and received a balanced concentrated diet with $12 \%$ protein and $27.5 \mathrm{mCal}$ of digestible energy. They were provided free access to water. All procedures on the animals were approved by the Ethical Committee on Animal Experimentation of the Faculty of Veterinary - Federal University of Pelotas (number 510).

Monitoring the mares. The mares were observed during daily health checks, for clinical signs of placentitis, like vulvar dis- charge and premature udder development. Transrectal palpation and ultrasonic examination were performed monthly to assess the fetus and placenta. The combined thickness of the uterus and placenta (CTUP) was measured at the placenta-cervical junction using a 5-MHz linear transducer (SonoVet600, Medison Co.Ltd, Seul, KR), starting at the fifth month of pregnancy until delivery. The CTUP was considered normal when the values was less than $8 \mathrm{~mm}$ between days 271 and 300 days of gestation, less than $10 \mathrm{~mm}$ between days 301 and 330 , and less than $12 \mathrm{~mm}$ after day 330 of gestation, as describe by Renaudin et al. (1997).

Mares with clinical signs of placentitis, like vulvar discharge and premature udder development, ultrasonographic changes to placental separation and/or thickening of the CTUP were treated with trimethoprim sulfamethoxazole $(25 \mathrm{mg} / \mathrm{Kg}$ IV, q $12 \mathrm{~h}$; Trissulfin ${ }^{\circledR}$ - Ouro Fino Saúde Animal, Cravinhos, SP-BR) and flunixin meglumine $\left(1.1 \mathrm{mg} / \mathrm{Kg} \mathrm{IV}\right.$, q 12 h; Banamine ${ }^{\circledR}$ - Schering Plough Saúde animal, São Paulo, SP-BR) for 10 days and altrenogest (0.088 mg/Kg, PO, q 24 h; Regumate ${ }^{\circledR}$ - Merck Animal Health Corporate headquarters, Summit, NJ-BR) until delivery.

Managing parturition. From thirty days prior to the date of delivery, the mares were maintained in paddocks near the maternity barn until the moment of delivery. After the chorioallantois ruptures, the mares were brought into the stable for assisted foaling. Immediately after their expulsion, the fetal membranes were weighed and were then placed in an "F" shape for gross evaluation. The two surfaces of the chorioallantois was examined for abnormalities of the color, areas devoid of microcotyledonary villi, thickened areas and presence of exudate on the chorionic surface (Schlafer 2004). Samples with $3 \times 3 \mathrm{~cm}$ dimension were obtained from nine points for each placenta, being: the pregnant horn, the non-pregnant horn, the uterine bifurcation, the uterine body, three parts of the umbilical cord, and the cervical star area. When placentas showed grossly lesions it was collected two samples in each point, one in the lesion and another in the transition area. Any other placental tissue with suspicious lesions was also sampled. All of the samples were fixed using formalin $10 \%$ prior to processing for histology. Histological sections (3- to $5-\mu \mathrm{m}$ thick) were mounted on glass slides and were stained using hematoxylin and eosin. The samples showed vacuolization on the chorionic epithelium in histologic evaluation were also stained using periodic-acid-Schiff (PAS) reagents.

The slides were evaluated using optical microscopy, the chorioallantois membrane was examined to integrity of chorionic and allantois epithelium, arrangement of microcotyledones, presence of alterations in all components of chorioallantois membrane, as inflammatory infiltrates, edema, necrosis and hypoplasia/ atrophy for microcotyledones. Placentas were considered with these histological features when they showed at least three points with damage.

The following data were recovered for each mare: age, number of parturitions, gestational age, time for placental expulsion, umbilical-cord length and placental weight immediately after expulsion were recorded, as well as whether clinical signs of placentitis had occurred during pregnancy.

Statistical analysis. All of the data were evaluated for normality using the Shapiro-Wilk test. The data for the response variables of the groups were reported as the mean values \pm SE. The independent variables were the histological features (no lesions, vacuolization, moderate infiltration, severe infiltration and hypoplasia/atrophy), placental grossly (no alterations, brownien-tan to grey appearance, loss or discoloration areas, devoid microcotyledons areas, edema, placentitis), and presence of clinical sings of placentitis. The dependent variables were data of mares: age, number of parturition, gestational age, time for placental expulsion, umbilical cord length and placental weight). Analysis 
of variance (ANOVA General) was performed to compare data of mares between groups of the histological features. Comparison of the means was accomplished using the post-hoc least-significant difference (LSD) test. Fisher's exact test was used to compare the placental grossly, the clinical signs of placentitis and the histological features. The statistical analysis was conducted using standard software. The level of significance was set at $\mathrm{p} \leq 0.05$.

\section{RESULTS}

In the gross placental evaluations $(\mathrm{n}=188), 79$ placentas without abnormalities were found, which had a red velvet-like chorionic surface. This appearance is caused by the presence of microcotyledons, and there is a bluish-colored smooth appearance containing prominent vessels in the allantoic surface (Fig.1a). In 87 cases, artifactual findings were observed, such as brownish-tan to grey colored tissue, colorless regions, irregular areas of discoloration, areas devoid of microcotyledonary villi and edema.

Furthermore, 22 of the placentas had suppurated or brown mucoidal material on the chorionic surface, which are features of placentitis (Fig.1d), and sometimes displayed areas devoid of microcotyledonary villi, while discoloration and thickening were frequently observed. In addition, it was observed features of amnionitis in three of these placentas.

No gross lesions were observed in the umbilical cords. Only small, keratinized plaques (amniotic plaques) and edema were observed in the ruptured portion. The average length of the umbilical cords $(\mathrm{n}=188)$ was $47.6 \pm 10.5 \mathrm{~cm}$, with minimal and maximal values of $30 \mathrm{~cm}$ and $84 \mathrm{~cm}$, respectively.

Histologic evaluation of 188 placentas was performed. No lesions were foundebserved in 129 of these placentas, the chorionic surface of which showed cuboidal to columnar cells in the areolar regions. The villar clumps, which had a randomized distribution, formed the microcotyle- dons, which were sometimes branched (Fig.1b).

In $30(30 / 129)$ of normal placentas, intense cytoplasmic vacuolization of the epithelial areolar cells was observed. The chorionic epithelium consisted of large cells containing vesiculated nuclei and frequently, lightly stained cytoplasm. Cells with thin projections at the periphery were also observed. Their cytoplasm was characterized by translucent material containing eosinophilic granules, compatible with histotrophic secretory (uterine milk) vesicles (Fig.2a). These vacuoles were positive PAS stain, suggestive of the presence of mucopolysaccharides (Fig.2b). The small rounded nuclei of these cells were occasionally located in the periphery.

In $40(40 / 188)$ of the placentas, the histologic features were consistent with inflammatory infiltrates. Nineteen $(19 / 40)$ of these placentas exhibited an infiltrate of mononuclear cells, with a prevalence of macrophages and lymphocytes (Figure 1f). The infiltration was mild to moderate and ranged from multifocal to generally coalescent. The other $21(21 / 40)$ placentas showed a severe infiltration with suppurative inflammation throughout the chorioallantoic villi, with the preponderance of neutrophils (Fig.1e). Suppurative exudates ranged from multifocal to coalescent, and eosinophilic material consisting of cellular debris was present between the chorionic villi. Only three of these placentas had aminionitis, with necrosis and the same inflammatory infiltrates mentioned above.

In addition to inflammatory changes, nineteen (19/188) placentas exhibited microcotyledonary hypoplasia or atrophy, characterized by the presence of short villi, some of which had a narrowed base, or the lack of villi (Figure 1c). Necrotic microcotyledons were also present at the chorionic surface.

The relationship between histological features of placenta with gross findings and data of mares are showing in Table 1 and 2.

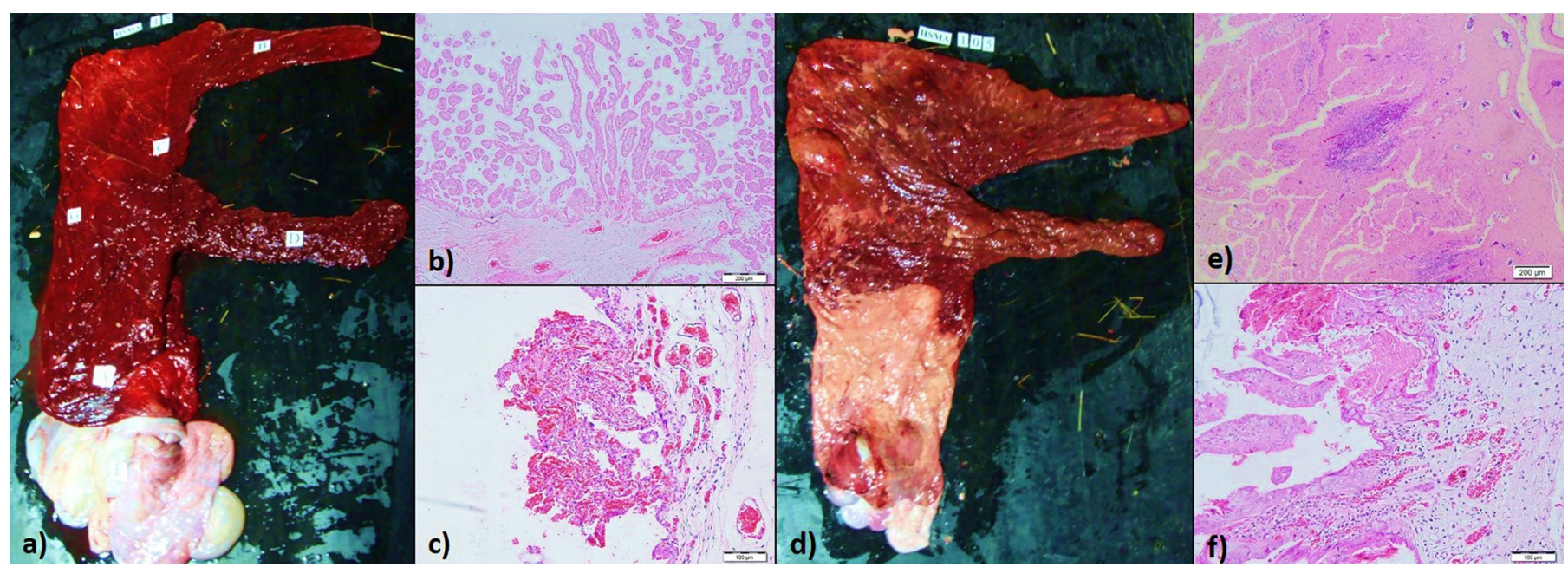

Fig.1. (a) Grossly evaluation of normal placenta, with velvet-like appearance of chorionic face. (b) Normal placenta in histology, showed chorionic face with randomized distribution of microcotyledones. (c) Microcotyledonary hypoplasia or atrophy, showed absent villi with necrosis of remaining microcotyledon. (d) Suppurated material with discoloration and thickening on chorionic surface of cervical star and placental body, featuring placentitis. e) Suppurative inflammation on the microcotyledones, with a predominance of neutrophils, necrosis and edema in chorionic face. (f) Mild to moderate inflammation of chorionic surface, with predominance of mononuclear infiltrate. 


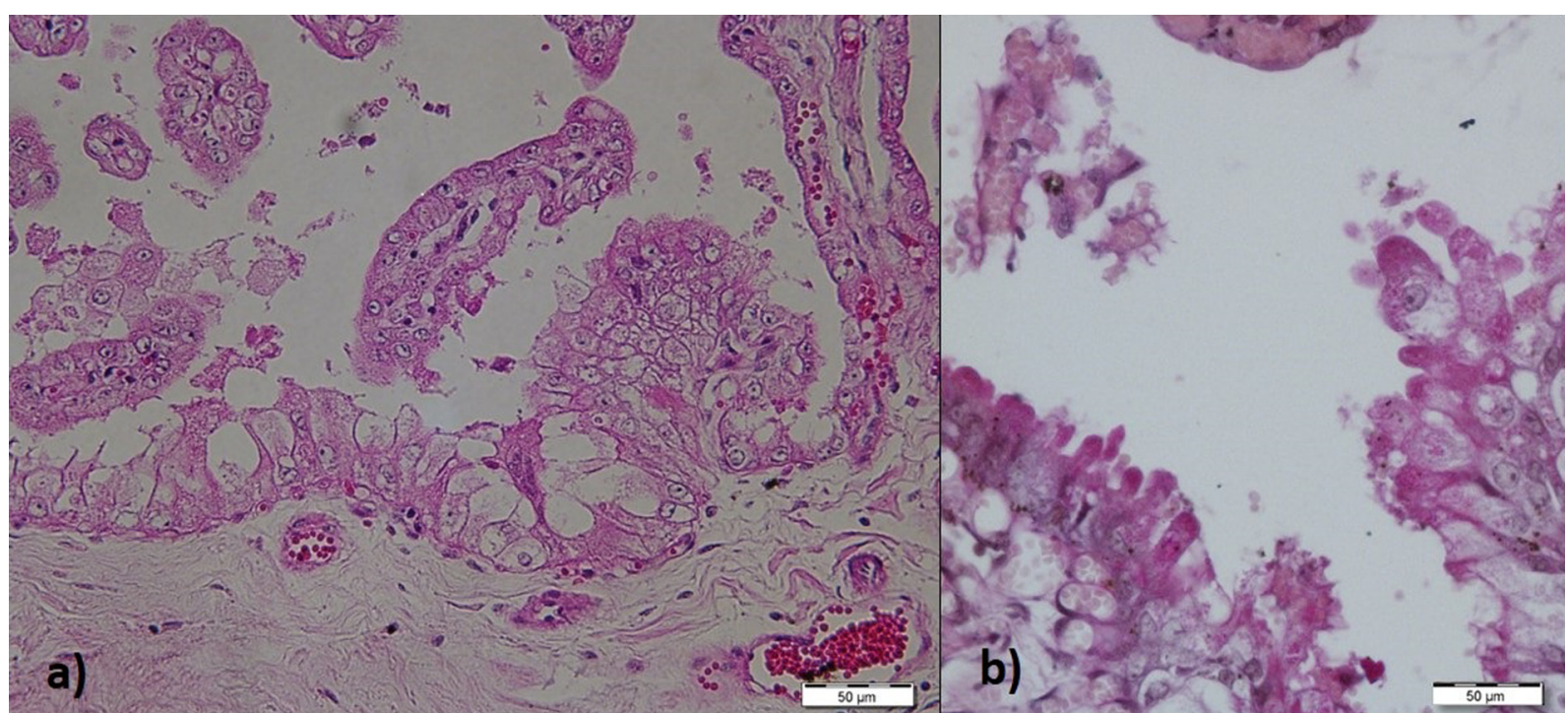

Fig.2. (a) Chorionic epithelium with intense cytoplasmic vacuolization. (b) PAS stained showed presence of mucopolysacharides inside of cytoplasmic vacuoles.

Table 1. Relation of placental grossly and histologic evaluation of Thoroughbred mares

\begin{tabular}{|c|c|c|c|c|c|}
\hline \multirow[b]{2}{*}{ Gross findings } & \multicolumn{2}{|c|}{$\begin{array}{c}\text { No lesions } \\
(\mathrm{n}=129)\end{array}$} & \multicolumn{2}{|c|}{$\begin{array}{c}\text { Inflammatory infiltrate } \\
(\mathrm{n}=40)\end{array}$} & \multirow{2}{*}{$\begin{array}{l}\text { Hypoplasia/ atrophy } \\
(\mathrm{n}=19)\end{array}$} \\
\hline & $\begin{array}{l}\text { No lesions } \\
(\mathrm{n}=99)\end{array}$ & $\begin{array}{c}\text { Vacuolization } \\
(\mathrm{n}=30)\end{array}$ & $\begin{array}{l}\text { Moderate infiltration } \\
(\mathrm{n}=19)\end{array}$ & $\begin{array}{l}\text { Severe infiltration } \\
\quad(\mathrm{n}=21)\end{array}$ & \\
\hline $\begin{array}{l}\text { No alterations }(\mathrm{n}=79) \\
\text { Artifactual }(\mathrm{n}=87)\end{array}$ & 57 & 12 & 0 & 2 & 8 \\
\hline Brownien-tan to grey appearance $(n=30)$ & 20 & 4 & 2 & 0 & 4 \\
\hline Loss or discoloration areas $(n=9)$ & 3 & 2 & 3 & 0 & 1 \\
\hline Devoid microcotyledons areas $(n=42)$ & 15 & 12 & 6 & 3 & 6 \\
\hline Edema $(n=6)$ & 2 & 0 & 4 & 0 & 0 \\
\hline Placentitis $(n=22)$ & 2 & 0 & 4 & 16 & 0 \\
\hline
\end{tabular}

Table 2. Placental histologic evaluation in Thoroughbred mares and its relation with the data of mare

\begin{tabular}{|c|c|c|c|c|c|}
\hline \multirow[b]{2}{*}{ Data of mare } & \multicolumn{2}{|c|}{$\begin{array}{l}\text { No lesions } \\
(n=129)\end{array}$} & \multicolumn{2}{|c|}{$\begin{array}{l}\text { Inflammatory infiltrate } \\
\qquad(\mathrm{n}=40)\end{array}$} & \multirow[t]{2}{*}{$\begin{array}{l}\text { Hypoplasia/ atrophy } \\
\qquad(\mathrm{n}=19)\end{array}$} \\
\hline & $\begin{array}{c}\text { No lesions } \\
(n=99)\end{array}$ & $\begin{array}{l}\text { Vacuolation } \\
\quad(n=30)\end{array}$ & $\begin{array}{l}\text { Moderate infiltration } \\
\qquad(\mathrm{n}=19)\end{array}$ & $\begin{array}{l}\text { Severe infiltration } \\
(n=21)\end{array}$ & \\
\hline Age & $9 \pm 0.36^{b}$ & $13 \pm 0.85^{\mathrm{a}}$ & $9 \pm 0.71^{b}$ & $10 \pm 0.94^{\mathrm{b}}$ & $9 \pm 1.05^{b}$ \\
\hline Number of Parturition & $4 \pm 0.29^{\mathrm{a}}$ & $6 \pm 0.76^{\mathrm{b}}$ & $3 \pm 0.55^{\mathrm{a}}$ & $4 \pm 0.74^{\mathrm{ab}}$ & $4 \pm 0.89^{\mathrm{a}}$ \\
\hline Gestational age (days) & $346 \pm 0.92^{a}$ & $349 \pm 1.99^{\mathrm{a}}$ & $338 \pm 3.13^{b}$ & $335 \pm 3.17^{b}$ & $347 \pm 2.93^{\mathrm{a}}$ \\
\hline Placental elimination time (min) & $42 \pm 4.2^{\mathrm{a}}$ & $39 \pm 4.09^{a}$ & $76 \pm 25^{b}$ & $45 \pm 18.68^{\mathrm{a}}$ & $41 \pm 6.78^{\mathrm{a}}$ \\
\hline Umbilical cord length $(\mathrm{cm})$ & $48 \pm 1.18^{\mathrm{a}}$ & $48 \pm 1.91^{\mathrm{ab}}$ & $50 \pm 2.55^{\mathrm{a}}$ & $46 \pm 2.73^{\mathrm{ab}}$ & $42 \pm 1.87^{b}$ \\
\hline Placental weight (kg) & $6.9 \pm 0.13^{\mathrm{a}}$ & $6.8 \pm 0.22^{\mathrm{a}}$ & $6.6 \pm 0.34^{\mathrm{a}}$ & $7.0 \pm 0.42^{\mathrm{a}}$ & $6.2 \pm 0.28^{b}$ \\
\hline
\end{tabular}

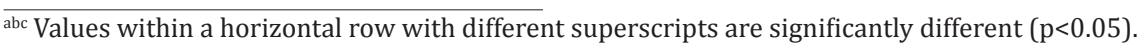

Mares with a vacuolated placental chorionic epithelium $(\mathrm{n}=30)$ did not show clinical signs, such as vaginal discharge or premature udder development, during pregnancy. The relationship between the clinical signs and the histological features of the placentas are shown in Table 3.

\section{DISCUSSION}

This study described gross and histological features in the placental evaluations in mares, and related these to clinical outcome. This could be used as an inducement for veterinaries to examine the placenta of all mares immediately after foaling, to gain information about potential complications for her and neonate. The placental evaluation it's useful to identifying risk situations to the neonatal foal, and unders- tand some clinical aspects of mares, which many times are not present during gestation.

Besides, the postpartum examination of the equine placenta should be an integral part of identifying events that occur during pregnancy and that might not be evident in the mare's clinical examination (Cotrill et al. 1991, Pirrone et al. 2014). In 93\% (176/188) of gross finding were consistent with placental histology. In this study, 90.9\% $(20 / 22)$ cases of placentitis were identified in gross evaluation, showing the presence of inflammatory infiltrates upon histology, as described by Schlafer (2004). Only two placentas without grossly alterations showed severe infiltration. Similar results were reported by Mays et al. (2002) in a study of ascending placentitis, which demonstrated 
Table 3. Clinical signs of placentitis and placental histologic evaluation

\begin{tabular}{lccc}
\hline & \multicolumn{3}{c}{ Clinical signs of placentitis } \\
\cline { 2 - 4 } & Yes (n=18) & No (n=170) & Total (n=188) \\
\hline No lesions & $3^{\mathrm{a}}$ & $96^{\mathrm{a}}$ & 99 \\
Vacuolization & 0 & $30^{\mathrm{a}}$ & 30 \\
Moderate infiltrate & $6^{\mathrm{b}}$ & $13^{\mathrm{b}}$ & 19 \\
Severe infiltrate & $7^{\mathrm{b}}$ & $14^{\mathrm{b}}$ & 21 \\
Hypoplasia/atrophy & $2^{\mathrm{a}}$ & $17^{\mathrm{a}}$ & 19 \\
Total & 18 & 170 & 188
\end{tabular}

ab Values within a vertical row with different superscripts are significantly different $(\mathrm{p}<0.05)$.

that not all mares with placentitis exhibited premonitory clinical signs or gross placental pathology.

However, two placentas without histologic alterations showed grossly findings of placentitis, corroborating with Schlafer (2004), who stated that some tissues exhibiting changes of questionable significance may require histopathology to differentiate artifacts from diagnostic lesions.

The placentas with a vacuolated chorionic epithelium did not show gross alterations. Positive PAS staining of the vacuolated cells confirmed their absorption of mucopolysaccharides. These could be characteristics of histotrophic secretion throughout gestation as described by Samuel et al. (1977) and Allen (2005). In our study, mares with a vacuolated placental chorionic epithelium were older $(13 \pm 0.85$ years) and had experienced a larger number of births $(6.46 \pm 0.76)$ than those in the other groups. These facts suggest that the presence of vacuolated cells indicate higher production of histotrophic secretion and that these mature mares had more integrated utero-placental unit. Nevertheless, no descriptions of the relationship between age and the vacuolization of the chorionic epithelium were found. The clinical importance of this finding in the histological evaluation of the term placentas was also not found in the literature.

Regarding the histological evaluation, the presence of a moderate level of infiltrates could be associated with chronic placentitis, as described by Hong et al (1993a). In our study, the mares with a moderate inflammatory infiltration into placenta also had higher time for placental expulsion $(76.56 \pm 25 \mathrm{~min})$. Edema and infiltration of mononuclear cells, particularly macrophages, can appear when the time for placental expulsion is higher, and could be related with intra- and extra-uterine autolysis (Schlafer 2004, Rapacz et al. 2012). However, in our study the presence of moderate level of inflammatory infiltrated predominantly of histiolymphocytic cells, low level of necrosis of the microcotyledons with discrete tissue damage, and the absence of autolysis characterized chronic placentitis in this group.

The lesions into placentas with a severe inflammatory infiltration resembled those described by Hong et al (1993b) as indicating acute placentitis. A shorter gestational age it was observed in all mares with inflammatory infiltrates. Acute cases of infection involve inflammation and the consequent increase in the level of pro-inflammatory cytokines, such as prostaglandins, which mediate events that lead to premature labor, as observed by Le Blanc et al (2002) and Mays et al. (2002) in experimental models.
The mares with hypoplasia or atrophy of the microcotyledons had lower placental weight, as described by Morresey (2005) and Laugier et al. (2011), and shorter umbilical-cord length when compared with placentas without alterations. The time for placental expulsion of these mares was similar to mares without lesions upon histological evaluation, and autolytic features were not observed in their placentas.

The average of umbilical-cord length $(55 \pm 0.9 \mathrm{~cm})$ was similar to that described by Wilsher \& Allen (2003), with the minimum and maximum lengths resembling those described by Whitwell \& Jeffcott (1975). Umbilical cord lesions, mainly torsions, are often associated with noninfectious abortion and/or stillbirths (Hong et al. 1993b, Smith et al. 2003, Laugier et al. 2011), generally due to excessively long umbilical cords. Furthermore, in our study no pathological features were observed in the umbilical cords, such as torsions or thrombosis.

The incidence of mares with clinical signs of placentitis was $9.5 \%$. All of the mares that exhibited clinical signs of placentitis during gestation were treated. The treatment may explain the occurrence of only moderate placental infiltration $(6 / 18$, Table 3$)$ and the lack of lesions $(3 / 18$, Table 3 ) in $50 \%$ of mares with clinical signs, allowing the pregnancies and delivery healthy foals. Just $39 \%$ of mares showed clinical sings during gestation, demonstrated severe inflammatory infiltrate in histologic evaluation $(7 / 18$, Table 3). This fact corroborates the results of the Murchie et al (2003) and Troedsson (2007) which suggested that treatment with a combination of antibiotics, anti-inflammatories and progesterone can positively affect the outcome of a pregnancy, allowing the delivery of healthy foals by mares that suffered placentitis.

In the other hand, the treatment of mares with placentitis during gestation does not provide default of lesions in the post-partum evaluation of placenta. In a study with twelve mares that received the same antibiotic and anti-inflammatory protocol of treatment, it was observed histopathologic features consistent with placentitis, as: hyperacute lesions in $41.7 \%$, acute lesions in $33.3 \%$ and chronic lesions in $25 \%$ of mares (Wendt et al. 2015).

The placentas of $15.8 \%(27 / 170$, Table 3$)$ of the mares showed inflammatory lesions upon histology, although no clinical signs of placentitis, such as vaginal discharge or premature udder development, and/or thickening of CTUP were observed during gestation. The diagnosis of placentitis is currently based on clinical signs and transrectal ultrasonography of the placenta, and these may be an effective method of placental assessment during gestation. However, many mares do not exhibit the classical signs of infection or the changes may not be detected with transrectal ultrasonography on the placenta, especially in early stages of placentitis (Troedsson \& Zent 2004, Le Blanc 2010). Therefore, some biomarkers can be useful to identified placentitis in early stages (Canisso et al. 2015). The recognized of these new diagnosis biomarkers and their relation with placental lesions upon histology need further investigation, with the aim of made an early diagnosis of placental failure.

In conclusion the gross evaluation of the postpartum 
placenta is an effective assessment method, the findings of which were consistent with the histological findings. In cases of the questionable significance of the gross appearance, samples should be sent for histological evaluation. The mares with a vacuolated placental chorionic epithelium were older and had experienced a larger number of births. Great part of the mares with inflammatory infiltrates did not showed any clinical signs of placentitis during gestation.

Acknowledgements.- We thank Fundação de Amparo à Pesquisa do Estado do Rio Grande do Sul (FAPERGS), the Coordenação de Aperfeiçoamento Pessoal de Nível Superior (CAPES), and Conselho Nacional de Desenvolvimento Cientifico e Tecnológico (CNPq) for financial support. We thank the members of Haras Santa Maria de Araras, Brazil, who provided the animals for research. We also thank Dr. Christopher Premanandan (College of Veterinary Medicine, Ohio State University, Columbus, $\mathrm{OH}$ ) and Dr. Donald Schlafer (College of Veterinary Medicine, Cornell University, Ithaca, NY) for their scientific input.

Conflict of interest.- None of the authors have any conflict of interest to declare.

\section{REFERENCES}

Abd-Elnaeim M.M.M., Leiser R., Wilsher S. \& Allen W.R. 2006. Structural and haemovascular aspects of placental growth throughout gestation in young and aged mares. Placenta 27:1103-1113.

Allen W.R. 2005. Maternal recognition and maintenance of pregnancy in the mare. Anim. Reprod. 2(40):209-223.

Canisso I.F., Ball B.A., Scoggin K.E., Squires E.L., Williams N.M. \& Troedsson M.H. 2015. Alpha-fetoprotein is present in the fetal fluids and is increased in plasma of mares with experimentally induced ascending placentites. Anim. Reprod. Sci. 154:48-55.

Cotrill C.M., Jeffers-Lo J., Ousey J.C., McGladdery A.J., Ricketts S.W., Silver M. \& Rossdale P.D. 1991. The placenta as a determinant of fetal well-being in normal and abnormal equine pregnancies. J. Reprod. Fert. 44(Suppl.): 591-601.

Hong C.B., Donahue J.M., Giles R.C., Petrites-Murphy M.B.Jr, Poonacha K.B., Roberts A.W., Smith B.J., Tramontin R.R., Tuttle P.A. \& Swerczek T.W. 1993a. Etiology and pathology of equine placentites. J. Vet. Diagn. Invest. 5:55-63.

Hong C.B., Donahue J.M., Giles R.C., Petrites-Murphy Jr M.B., Poonacha K.B., Roberts A.W., Smith B.J., Tramontin R.R., Tuttle P.A. \& Swerczek T.W. 1993b. Equine abortion and stillbirth in central Kentucky during 1988 and 1989 foaling seasons. J. Vet. Diagn. Invest. 5:55-63.

Laugier C., Foucher N., Sevin C., Leon A. \& Tapprest J. 2011. A 24-year retrospective study of equine abortion in Normandy, France. J. Equine Vet. Sci. 31:116-123.

Le blanc M.M., Giguere S., Brauer K., Paccamonti D.L., Horohov D.W., Lester G.D., O’Donnell L.J., Sheerin B.R., Pablo R. \& Rodgerson D.H. 2002. Premature delivery in ascending placentitis is associated with increased expression of placental cytokines and allantoic fluid prostaglandins E-2 and F-2 alpha. Theriogenology 58:841-844.

Le Blanc M.M., MacPherson M. \& Sheerin P. 2004. Ascending Placentitis:
What We Know About Pathophysiology, Diagnosis and Treatment. AAEP Proc. 50:127-143.

Le Blanc M.M. 2010. Ascending placentitis in the mare: an update. Reprod. Domest. Anim. 45:28-34.

Leiser R. \& Kaufmann P. 1994. Placental structure: in a comparative aspect. Exp. Clin. Endocrinol. 102(3):122-134.

Mays M.B.C., Le Blanc M.M. \& Paccamonti D. 2002. Route of fetal infection in a model of ascending placentitis. Theriogenology 58:791-792.

Morresey P.T. 2005. Prenatal and perinatal indicators of neonatal viability. Clin. Tech. Equine Pract. 4:238-249.

Murchie T.A., MacPherson M.L., LeBlanc M.M., Luznar S. \& Vickroy T.W. 2003. A microdialysis model to detect drugs in the allantoic fluid of pregnant pony mares. Proc. Am. Assoc. Equine Pract. 49:118-119.

Pirrone A., Bianco C., Boldini S., Sarli G. \& Castagnetti C. 2014. Histomorphometric parameters and fractal complexity of the equine placenta from health and sick foals. Theriogenology 3:1-7.

Rapacz A., Pazdzior K., Rás A., Rotkiewicz T. \& Janowski T. 2012. Retained fetal membranes in heavy draft mares associated with histological abnormalities. J. Equine Vet. Sci. 32:38-44.

Renaudin C.D., Troedsson M.H.T., Gillis C.L., King V.L. \& Bodena A. 1997. Ultrasonographic evaluation of the equine placenta by trans rectal and transabdominal approach in the normal pregnant mare. Theriogenology 47(2):559-573.

Samuel C.A., Allen W.R. \& Steven D.H. 1977. Studies on the equine placenta. III. Ultrastructure of the uterine glands and the overlying trophoblast. J. Reprod. Fertil. 51(2):433-437.

Schlafer D.H. 2004. Postmortem examination of the equine placenta, fetus, and neonate: methods and interpretation of findings. Proc. Am. Assoc. Equine Pract. 50:144-161.

Smith K.C., Blunden A.S., Whitwell K.E., Dunn K.A. \& Wales A.D. 2003. A survey of equine abortion, stillbirth and neonatal death in the UK from 1988 to 1997. Equine Vet. J. 35(5):496-501.

Troedsson M.H.T. \& Zent W.W. 2004. Clinical ultrasonographic evaluation of the equine placenta as a method to successfully identify and treat mares with placentitis. Vol. 1. Proc. Workshop on the Equine Placenta, Lexington, KY, p.66-67.

Troedsson M.H.T. 2007. High risk pregnant mare. Acta Vet. Scandinavica 49(Suppl.1):S1-S9.

Wendt C.G., Curcio B.R., Vieira P.S., Oliveira L.C., Pazinato F.M., Feijó L.S., Noguera D.M. \& Nogueira C.E.W. 2015. Histopathology of the placenta after pregnancy time related induction of placentitis in mares. Anais $21^{\circ}$ Congresso Brasileiro de Reprodução Animal, Belo Horizonte, p.117.

Wilsher S. \& Allen W.R. 2003. The effects of maternal age and parity on placental and fetal development in the mare. Equine Vet. J. 35(5):476483.

Wilsher S. \& Allen W.R. 2012. Factors influencing placental development and function in the mare. Equine Vet. J. 44(Suppl.s41):113-119.

Wilsher S., Ousey J. \& Allen W.R. 2005. Gross and histological observation on placentae from abnormal pregnancies. Proc. Workshop on Comparative Placentology in Havemeyer Foundation Monograph Series 17:5758

Whitwell K.E. \& Jeffcott L.B. 1975. Morphological studies on the fetal membranes of the normal singleton foal at term. Res. Vet. Sci. 19:44-55. 